\title{
Herding Cats
}

\author{
László Bartosiewicz
}

\section{Introduction}

'Interdisciplinarity' remains a buzzword in archaeology: a divide between science and humanities (Fredengren 20I3:54) has precluded the systematic integration of data, methods and vocabulary. Lidén and Eriksson (20I3) reviewed misuses of archaeological science by both archaeologists and natural scientists, including the largely performative adoption of each other's results. Long-standing traditions of natural science ('science' henceforth) and humanities in archaeology are at risk of diverging from one another. Beyond entanglement (Fredengren 202I) is a commendable effort to better involve animal studies in archaeology. It inspires reflection on how human-animal relations are coded in key concepts I choose to discuss here. My attempt to bone up on theories developed in animal studies revealed challenges facing the study of animal remains and interdisciplinary archaeology in general.

Analysing animal remains in archaeology seems a distinctly positivist, empirical exercise. Whether in search of patterns or testing hypotheses, we invariably study the bodies of dead animals. These data, however, can be too scarce to fit statistical analyses due to past human behaviour, an integral part of the taphonomic process in archaeology (Noe-Nygaard 1987; Magnell 20I I) contaminating the purely 'zoological' record. Animal bodies are broken up and scattered in culturally different ways making their reconstruction too often impossible. Trying to profit from this inevitable bias led to a 'human turn' in my career. Focusing on relationships reveals domesticates to be culturally constructed, endowed with idiosyncratic meanings,

Department of Archaeology and Classical Studies, Stockholm University

laszlo.bartosiewicz@ofl.su.se 
classed into culturally determined categories. Fredengren (202I:I4) posits that animals' 'bodies stretch tentacularly through material culture'. To my mind, domesticates are material culture, shaped by human aspirations, decisions, sometimes mistakes in breeding. Even their morbidity shows cultural impact (Bartosiewicz 202I). However, animals are not passive objects. A trained draught ox is invested with agency: it represents emotional value and social capital through interactions with its owner far beyond the price of its tough meat (Bartosiewicz 2006).

\section{'What's in a name?'}

Firstly, the epistemic difference between 'archaeozoology' and 'zooarchaeology' deserves attention. The first is more inductive, traditionally practiced by zoologists or veterinarians (Boessneck I990), the second relies more on deduction, having emerged along with New Archaeology in the I970s. Diachronic oscillations in British usage (Bartosiewicz 2019a:30) indicate how the philological nuance has reflected trends in archaeology (Bobrowsky 1982) while a coherent theoretical frame remains to be drafted. In the meantime, unrelated to the archaeological engagement with animals encompassed by both competing strands, interest in animals culminated in the 'animal turn' (Ritvo 2007; Wolfe 2009) in other humanities.

Rooted in human exceptionalism, the vaguely defined notion of 'agency' (Ritvo 20I8:232) was criticized on theoretical grounds (Dobres \& Robb 2000:4). Applying it to animals calls for added scrutiny, as its rational and premeditated elements become inaccessible (Despret 2013:30). Animal traits, including inter- and intraspecific behaviour can make agency visible on bones (Bartosiewicz \& Gál 2008). 'Agency' may even survive animals in material culture as bone artefacts preserve semiotics related to animals (Choyke 20I0). Species used in craft also reflect gender relations (Fredengren 202I:I4): in Hungary, Late Neolithic pendants of stags' canine teeth seem unrelated to gender while their bone imitations occur only in female graves (Choyke 200I). Meanwhile, Spondylus shell beads and wild boar mandibles are typical in male burials (Anders \& Nagy 2018:189). The underlying significance of species is perhaps most striking in tools made of bones of dubious resilience, compromising the sheer functionality of the object. Examples include a fishhook carved from a pike dental bone from the Late Neolithic lake dwelling of Saint Blaise/Bains des dames in Switzerland (Choyke \& Bartosiewicz I994) and a cache of projectile points made of porous bezoar goat horn cores at Early Bronze Age Arslantepe, Turkey (Choyke 20I2:89). 


\section{Taxonomy}

Taxonomy means classifying on a relational basis (Sokal I974:III6). It is important to see by what means and where boundaries are drawn (Fredengren 202I:I8). Simplifying taxonomies is challenging, as their entangled parts interact, some in conflicting ways. In the interest of consistent communication animal experts in archaeology adopted Linnaean nomenclature (Gentry et al. 2004), acknowledging that animal classifications in the past must have been as diverse as is shown by folk taxonomies in a number of languages today. Animals have always carried a semantic load, influencing their perception, naming and vernacular classifications.

Prehistoric technology is widely characterised by the chaine opératoire (Pelegrin et al. 1988). Emphasis on transformation, however overshadows sociality and meaning (Dobres 2000:154), very important in processing animal bodies. Schibler's (198I) bone tool typology considers the species/ anatomy of the raw material. However, Linnaean and veterinary nomenclatures can create types dominated by modern perceptions of animal corporeality (Bartosiewicz \& Choyke 1994). The manufacturing continuum (Choyke 1997) tempers this influence: objects are evaluated on the basis of how patterned the choice of animal species/skeletal part was, to what extent it was modified and how intensively it was used.

Entangled taxonomies can be confusing. Obvious, discontinuous groupings are easier to perceive (Sokal I974:III6). Dichotomic simplifications however are inherently reductive and misrepresentational. De-structuring hierarchical binary categories such as nature/culture (Fredengren 20I3:55), self/other or human/nonhuman is central to posthumanist thinking (Åsberg \& Braidotti 20I8) affecting animal studies. Exaggerating human-animal unity, on the other hand may 'paradoxically work to reinforce the humananimal boundary' (Ritvo 2007:II9) as it acknowledges the power of this arbitrary distinction.

\section{Significant others?}

Although the theoretical concept of 'othering' is absent from mainstream archaeozoology, distinction/discrimination using animals can be observed. While collective 'othering' based on animal metaphors is hard to trace in archaeology, varieties of food habits offer some examples. Eating dogs is currently being depicted in Western media as a despicable custom in the Far East. This tradition, however was well and alive in post-World War II Europe (Geppert 1990). Eating pork or horse meat have been likewise divisive in known history. Consuming curious creatures as a means of high- 


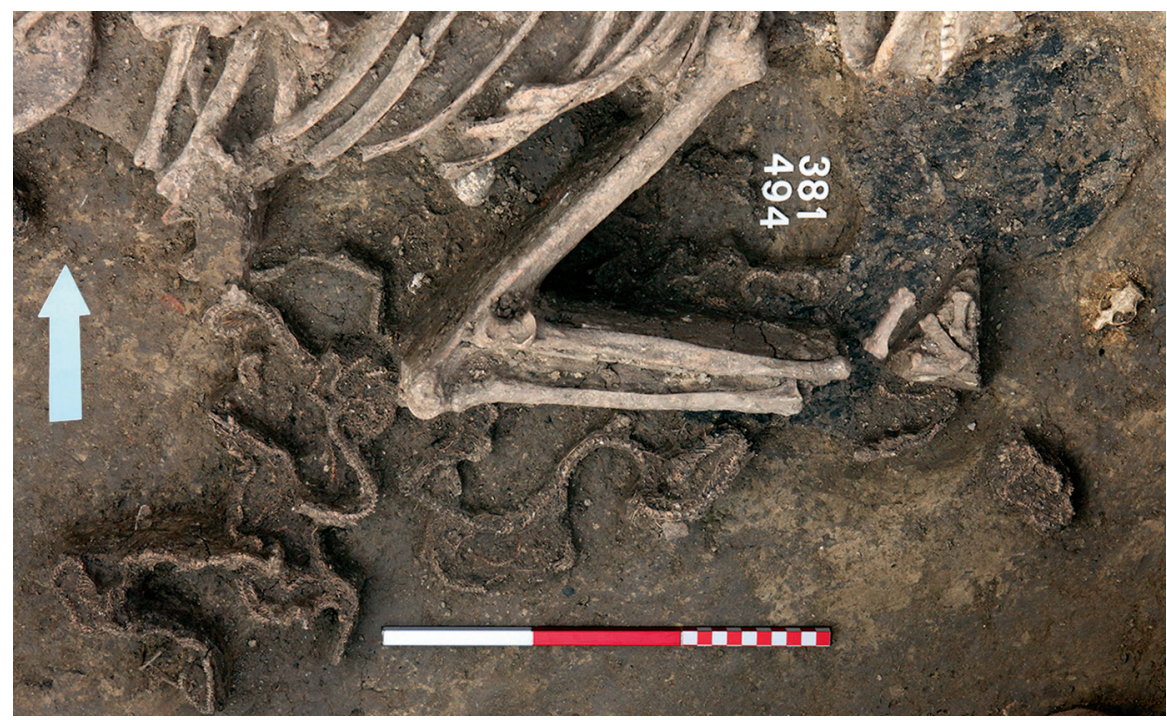

Figure I. Snake skeletons in the area of the left forearm of a 48-52 year old Copper Age woman at Pusztataskony, Hungary. The skull of a water vole near the right edge of the picture is a natural deposit (Bartosiewicz et al. 2013). Scale: $30 \mathrm{~cm}$.

status self-representation is the opposite side of the same phenomenon (Albarella \& Thomas 2002; Bartosiewicz \& Gál 202I).

'Othering' by association with animal bodies is better visible in the archaeological record. Since the Paleolithic, some were interred with strange assortments of species (Vanhaeren \& D'Errico 2005; Grosman et al. 2008). Such persons are commonly labelled 'shamans' linked to transformations of gender and the human-animal state. A technical difficulty with such burials is that being unique they lack the repetitive element, instrumental in de-coding rituals. The only sure fact is that unexpected animals occur in mortuary contexts.

At Pusztataskony, Hungary, an old woman was laid to rest on her left, conforming to common burial rites around 4000 BCE. However, in contrast to the oblong graves dug near households of the time (Raczky \& Anders 2008:I5I) she lay in a round pit in remote marshland in the company of a hare (Bartosiewicz et al. 20I3:8I) and a dozen entangled, non-venomous snakes (Figure I). No prehistoric parallel is known. Seven unrelated burials with snakes (five women and two children) came to light in the ninth- to eleventh-century CE Ravna-Slog cemetery, Serbia (Milosavljević 202I:IOI). In this ritual at least a pattern of repetition could be observed.

It is impossible to tell whether such burials mean othering in a negative or positive sense. Snakes can fall between poles of the Aesculapian (healer) and Biblical (Satan) perception. Dogs seem easier to interpret, better known 
for their agency and familiar presence. Along with cherished entanglements with humans as work companions and pets (Armstrong Oma 2020; Cockram 20I 8), abusive attitudes in this 'partnership' are clear in bone injuries some dogs had to sustain (Storå et al. 2020), a reflection of their contentious status. Dogs seem to be the animal of choice in othering humans in death. The disfigured carcass of a male dog with entangled legs was apparently thrown over the extended skeleton of a 40-50 year old woman in the sixth-century CE cemetery of Ménföcsanak, Hungary (Bartosiewicz 20I5:254). People tossed six dead dogs in a pit along with a dismembered elderly woman outside the consecrated Catholic cemetery in eleventh-century Visegrád-Várkert, Hungary (Vörös I99ı:I 86). All these examples, selected on the basis of animals, involve women. As seen in examples of falconry (Back Danielsson 20I 4:270; Bartosiewicz 20I2:I8I), associations with animals need to be seen relationally, using gender as an analytical concept. Instead of rigid categories of sex, intersections need to be considered in relation to other power structures such as class, race, and species whenever possible. Whether the connotations of animals were positive or negative, this raises the possibility of gendered 'othering' utilizing animal bodies.

\section{Monsters and hybrids}

Transcendental beings were reality to many in the past. Monsters are difficult to discuss in osteological terms in want of evidence. However, Otto Von Guericke's I 678 honest scientific effort to reconstruct a unicorn by unwittingly 'hybridizing' bone finds of various fossil ungulates (Bartosiewicz $\&$ Choyke 2020:4) could be a case in point. Unicorns are borderline creatures in a sense that they conceptually overlap with real animals. According to Pluskowski (2004:293), while identifying a 'unicorn horn' artefact as a narwhal tusk offers proper information about its geographical and cultural origins, it also needs to be considered as a unicorn, addressing conceptualizations in different cultural contexts.

Material proof of bestiality, a recurring topic in mythologies and folklore is also absent in archaeology. An Early Modern Age thought experiment in Scotland focusing on bestiality involving apes, however, reveals multiple aspects of human-animal hybridization. Conflating apes and 'savages', the birth of liminal creatures to women posed a threat as an eerie form of material transformation (Wells 20I8:I30). It illustrates how pervasive entanglements overshadow the humanist logics of sexuality, species, and race (Åsberg et al. 2011:220).

Around the turn of the first millennium BCE urn cemeteries appear all over Hungary signalling shifting views of afterlife (Király 2015:5). De- 


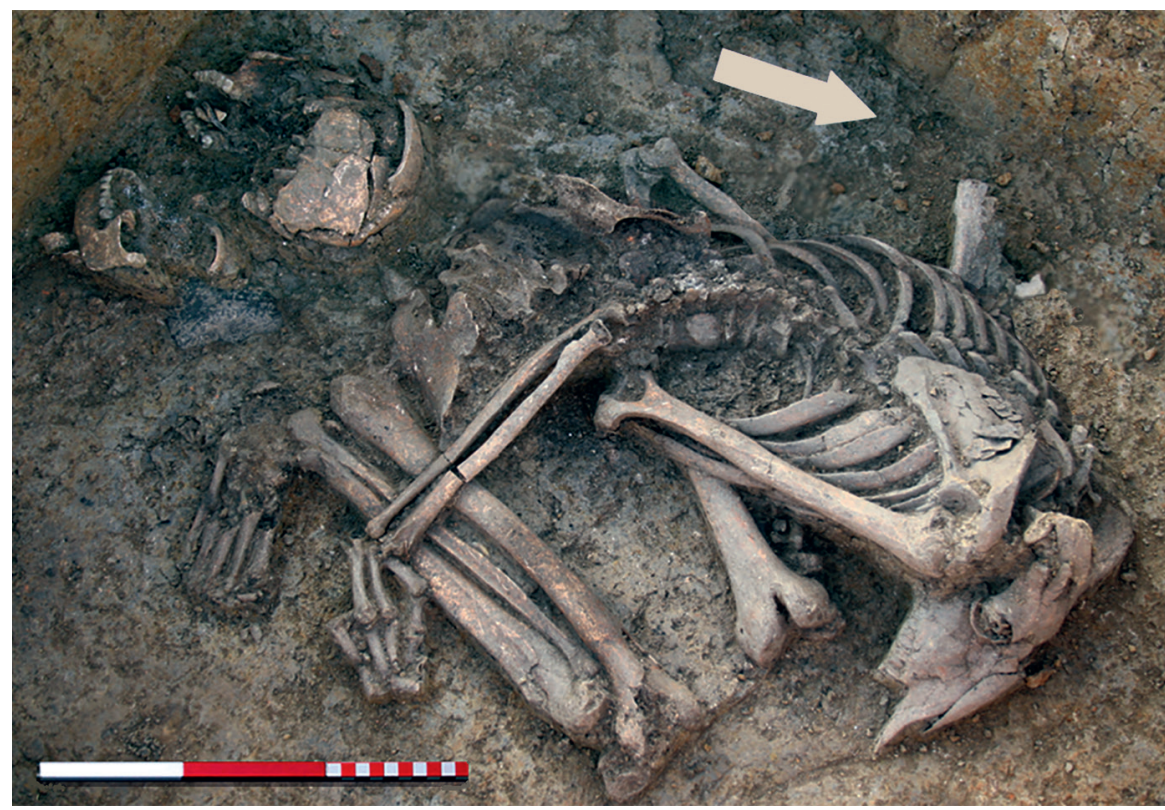

Figure 2. Burial of the Late Bronze Age 'sheep-headed person', Pácin-Alharaszt, Hungary. (Archaeological Archives, Herman Ottó Múzeum, Hungary. Inv. No.: 6922-2020). Scale: $30 \mathrm{~cm}$.

ciphering concepts related to the 'other world' are complicated by an increasing number of inhumations within settlements. At Late Bronze Age Pácin-Alharaszt, the tightly contracted body of a decapitated adult person was laid in a large but shallow oval pit with the head and five neck vertebrae found at their rear. It was replaced by the head of a young adult sheep (Figure 2). While the grave still awaits detailed anthropological as well as archaeological analysis, the phenomenon is relevant to hybridity in an unknown funerary context.

As with shamans, interspecific boundary-crossing is integral to magical practices and mythology. Some archaeological finds of animals were likely used by the living in evoking mythical hybridity. In addition to complex finds in watery places (Fredengren 2021:20), antler headdresses (Bartosiewicz et al. 20I7) and other 'ornaments' worn by humans functioned way beyond decoration (Bar-Yosef Mayer et al. eds 20I7). Trophies represent a murderous appropriation of animal agency, the might of fearsome game. The only lion bone artefact known from Hungary is the perforated phalanx from an unusually large dewclaw, a possible pendant. It was recovered from a Copper Age refuse pit at Tolna-Mözs. The age, gender and social status of its owner is thus unknown. Whether it was a first-hand trophy, an heirloom linking generations or an amulet making 


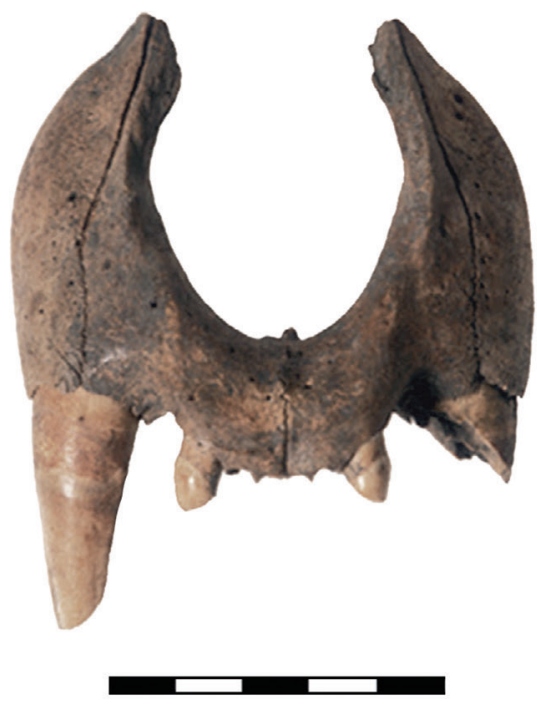

A

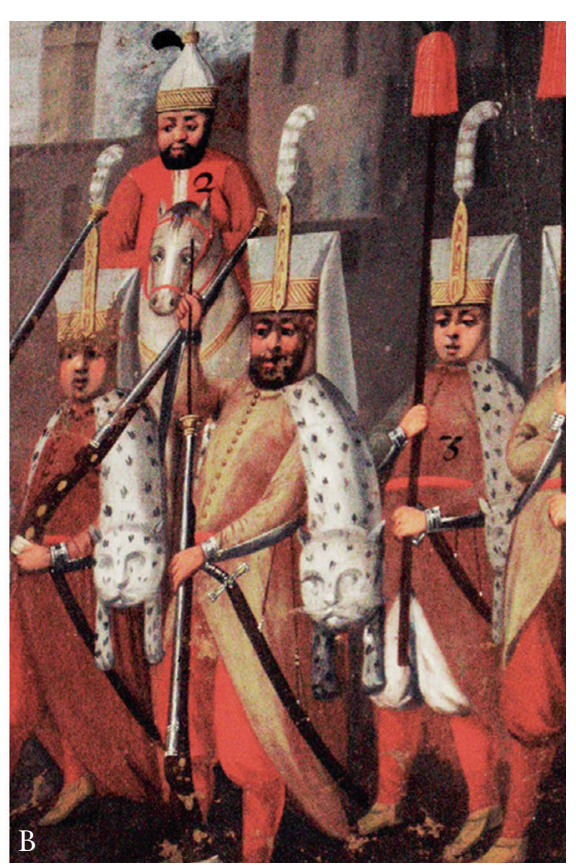

Figure 3. A: Worked leopard bone from fourteenth- to fifteenth-century Segesd, Hungary (Bartosiewicz 200I); B: Turkish officers wearing leopard skins in the 1657 procession of Sultan Mehmed IV in Istanbul. Painting commissioned by Claes Rålamb (Nordiska Museet, Stockholm). Scale: $5 \mathrm{~cm}$.

rounds in the community, it certainly represented a special force (Daróczi et al. 2020:479).

A pair of evidently imported leopard fangs were found among fourteenth to fifteenth-century rubble in the royal city of Segesd, Hungary. Bones of the snout holding the canine teeth of a large male had been carefully cut off (Figure $3 \mathrm{~A}$ ). The reverse side (cut surface) of this artefact was polished in use. In the absence of perforations one may hypothesize that the bone was sewn to a soft material displaying the fangs. Leopard skin capes, initially worn by knights of the Teutonic Order founded during the Third Crusade in Palestine, became popular among high-ranking military in Europe and janissaries in the Ottoman Turkish army (Figure ${ }_{3} \mathrm{~B}$ ). We cannot tell whether medieval warriors actually felt any transformation thanks to formal animal 'empowerment'. The threat, however is clear, even if the animal is no longer active to display it himself. Hybridity, in this broad sense, is archaeologically manifested in gestures that seek to combine human and animal agency both in life and death. Perceptions of animals motivating such efforts clearly vary within a wide range. 


\section{Killability}

Meat acquisition requires killing, but animal lives and bodies have also been destroyed in rituals in the broadest sense (Magnell 20II). Spectacular animal rites can target remembrance (Price 20I0:136), provoking guilt in participants counterweighed by sacralisation that fosters bonding through shared aggression (Burkert I972).

The distinction between profane/ritual is yet another dichotomy one should tackle since the trope of sacrifice affects many processes (Fredengren 2021:22). Stolle (2020:193) observes low and high intensity butchery, the latter in connection with communal feasting. Relational questions of inequality and injustice, and degrees of situated entanglement, however defy a binary approach in this case as well. Food has ritualistic/sacrificial, psychological, ethical, and ecological dimensions (Wolfe 2009). While sacrifice is to convey messages to the other world, sharing meat constructs and reinforces earthly social hierarchies as is well-documented in classical Antiquity (Faraone \& Naiden eds 20I2).

Murdering humans is a religious stipulation, partially transposed to animals. Cognitive dissonance is alleviated through regulating the way livestock is slaughtered in 'humane' ways (Bartosiewicz et al. 2008). Throat slitting in kosher and halal tradition (Figure $4 \mathrm{~A}$ ) is not aimed at damaging the bone. However, fine traces of a metal blade were found in this area on the first neck vertebra of an alpaca at sixteenth-century Incarracay, Bolivia (Figure $3 \mathrm{~B}$ ). The Inka killed llamas disrupting their hearts by hand through a slit in the chest. Guaman Poma (I6I5:I60), however, warns: 'Do not kill [...] like in the time of idolatry, but do it like Christians [...], by cutting the ram's neck.' Christianity has never regulated the slaughter of 'insentient' animals. This issue likely arose in a colonial setting as a tool of ideological dominance.

Merciful killing is not always the aim as shown by the example of surviving bullfighting rituals. Torturing animals at the table during feasting is known from Early Modern Age England, fitting the trans-mutational process from animal through flesh to meat (Raber 2018).

As Fredengren (202I:23) correctly observes, what is expendable as sacrifice varies broadly between cultures. It was not beasts of burden or old animals but healthy adults that were slaughtered at Iron Age Uppåkra (Magnell 20II:202), while in Rome the health of sacrificial animals was not stipulated (Varro I97I:II V:II). One stallion and one male dog were placed in each of three Migration Period deposits at Keszthely, Hungary. One of the horses had advanced chronic lesions, including the full fusion of $\mathrm{I} 7$ vertebrae, for years rendering him unfit as a mount (Bartosiewicz \& Bartosiewicz 


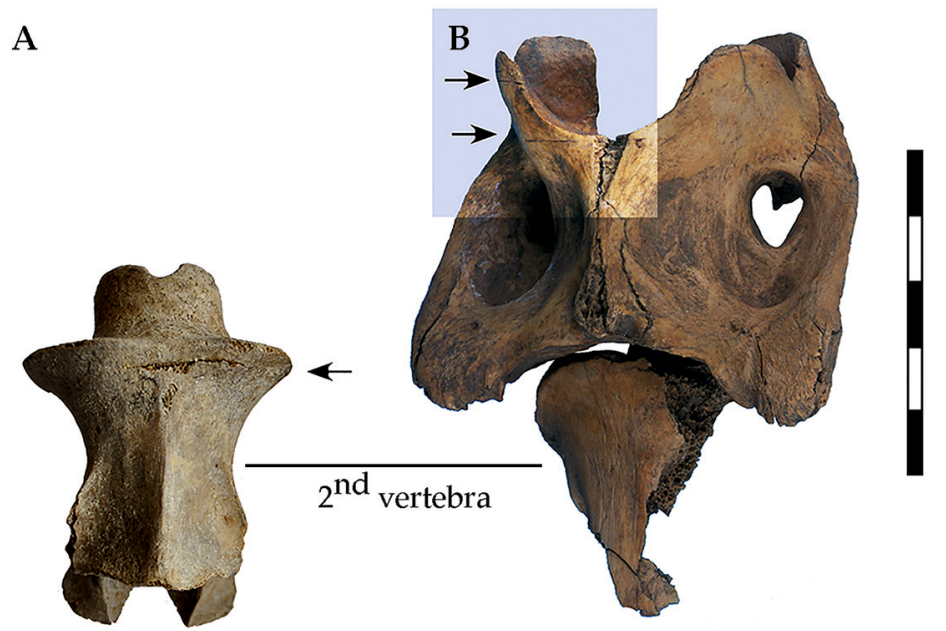

Figure 4. A: Fine metal cut mark attributable to halal slaughter on the ventral surface of the second neck vertebra of a seventeenth-century Ottoman Period sheep, Visegrád, Hungary (Bartosiewicz \& Gál 20I8); B: Metal cut marks on the ventral part on the first vertebra (highlighted) of a sixteenth-century alpaca, Incarracay, Bolivia (Bartosiewicz I999). Scale: $5 \mathrm{~cm}$.

2002:829). This horse required human care, suggesting emotional worth. Ultimately, however it was dispatched in a poorly understood 'sacrifice'.

Animal agency is manifested confronting powerful game. The delayed adoption of domestic cattle at Neolithic Çatalhöyük, Anatolia, may stem from the semiotic and social significance of its wild ancestor, the aurochs (Arbuckle 2015:232). In a comparable way, killing lions is more than a test of courage, it is also a token of associated male prowess (Hazzah et al. 2009), confirming Russell's (20I2:159) proposition that hunting is entangled in sex and gender relations. A likewise important social dimension of entanglement is that communal hunts for dangerous game need to be wellorganized. Many of the rare prehistoric lion bones from Southeast Europe and Anatolia represent meat-bearing body parts and show that the carcass was butchered (Bartosiewicz 2019b:28I, Daróczi et al. 2020:475). Consuming lion meat must have had strong ritual connotations.

\section{Beyond bushmeat}

Human and animal welfare have become inseparable from each other and the environment. Osteological symptoms of animal disease and injury can reveal situated relations with humans from a posthumanist perspective (Bartosiewicz 2020). Fredengren (2021:28) notes that 'bodies are both carrier bags and ecosystems'. Thus their microbiota include pathogens linking 


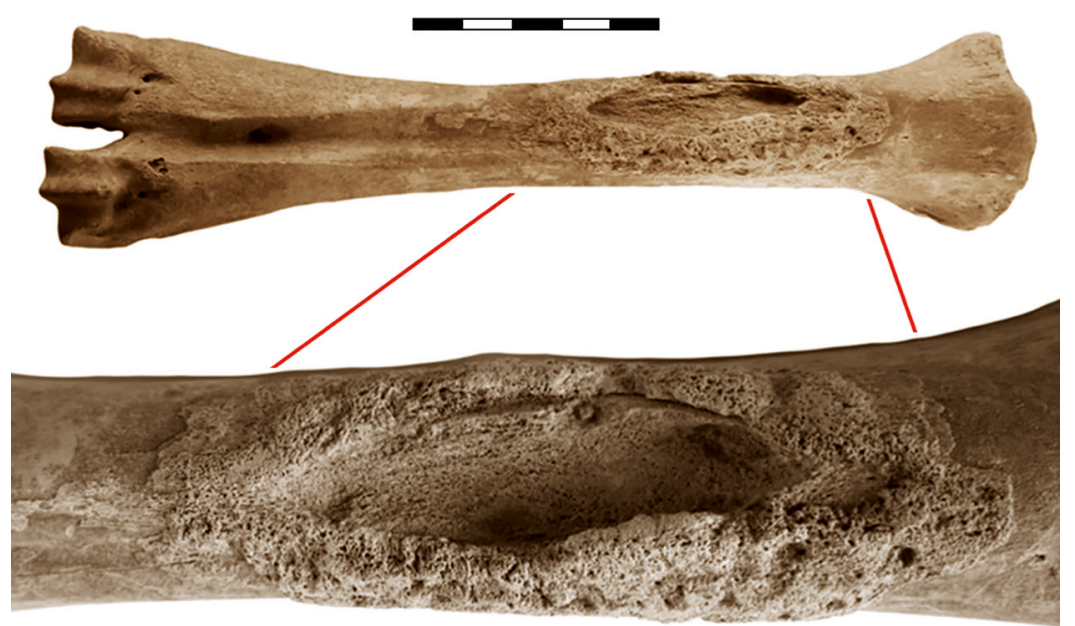

Figure 5. Cavernous lesion with osteosclerotic ring in the metatarsus of a Late Neolithic cow, Herpály, Hungary. Below: lesion enlarged (Bartosiewicz 20I3). Scale: $5 \mathrm{~cm}$.

the animal not only to its environment but also to individuals of its own and other species. Interactive socioecological systems giving rise to zoonoses (infectious diseases shared among different species) involve humans, animals, and pathogens in specific environments. Archaeological applications of the One Health perspective (Bendrey et al. 2019) acknowledge this essential link in an interdisciplinary setting. Their breaking with the anthropocentric approach and considering components in a holistic and integrated way is comparable to the endeavours of animal studies in humanities.

Ancient DNA evidence of tuberculosis in Late Neolithic humans (early fifth millennium BCE in Hungary; Masson et al. 2013) is among the earliest confirmed cases in Europe. It supports the visual identification of a wreath-like sclerotic ring around the tuberculotic-looking cavern on a cow metatarsus from coeval Herpály, Hungary (Figure 5), although this macroscopic observation needs DNA support. Reflecting present-day public health concerns focused on humans, however DNA research has been quite anthropocentric in archaeology: human samples tend to be prioritized in costly laboratory analyses of disease. Bendrey et al. (2019:102) cite five human remains with confirmed biomolecular evidence of brucellosis (infectious abortion), although there are no tested specimens of equally affected animals from archaeological sites. To date, ancient DNA of bubonic plague is likewise studied in human remains in spite of the known involvement of rodents (Susat et al. 202I). 


\section{Epilogue}

By the 1850 a archaeology emerged in close cooperation with zoology (Kristiansen 2OI4:I4). Referring to Steenstrup's ground-breaking work on prehistoric shell middens (Forchhammer et al. I856) three decades ago Bökönyi (I992:400) lamented that the necessity of such collaboration still had to be repeatedly emphasized. In fact, knowledge keeps increasing by an immense rate and sophistication with little convergence between science and humanities.

As my small set of selected archaeological examples shows, there are any number of ways in which discussions advocated in Beyond entanglement (Fredengren 202I) can go on in animal studies in archaeology itself. Stimulating ideas in the keynote paper helped identify at least two additional areas, bone manufacturing and paleopathology, that may profitably use ruling trends in posthumanist animal studies.

However, the languages of science and humanities somehow grew apart, even within English that has become the lingua franca of scholarly conduct. Publication in peer-reviewed journals (required in science) and synthetic books (targeted more in humanities) influences style. This difference is carried on to the way successful grant applications 'must' be written adding institutionalized market pressure to the divide. Substantial and inclusive communication is necessary as the arsenals of terms and principles to be reconciled can burden multidisciplinary discourse.

Language, a cultural construct, shapes our thinking. Linguistic diversity is important in archaeology in communicating authentic academic information to local communities of the broad public. Curiously, there is even variability in the degree to which the semantics of science and humanities differ within various European languages. Prodding Schrödinger's (I935) and Derrida's (2006) cat into the same fold will be a long-awaited intellectual achievement benefiting the future of archaeology - as a whole.

\section{Acknowledgements}

Grateful thanks are due to Gábor András Szörényi (Herman Ottó Múzeum, Hungary) who provided field documentation on the unpublished find from of Pácin-Alharaszt. The final version of my manuscript was greatly improved thanks to editorial remarks by Alison Klevnäs and Sophie Bergerbrant. 


\section{References}

Albarella, U. \& Thomas, R. 2002. They Dined on Crane: Bird Consumption, Wild fowling and Status in Medieval England. Acta Zoologica Cracoviensia. Vol. 45 pp. 23-38.

Anders, A. \& Nagy, E.G. 20I9. Making the Invisible Visible: Expressing Gender in Mortuary Practices in North-Eastern Hungary in the 5 th millennium BCE. In: Koch, J.K. \& Kirleis, W. (eds), Gender Transformations in Prehistoric and Archaic Societies, pp. I83-204. Leiden: Sidestone.

Arbuckle, B.S. 20I3. The Late Adoption of Cattle and Pig Husbandry in Neolithic Central Turkey. Journal of Archaeological Science. Vol. 40(4) pp. I805-I8I5.

Armstrong Oma, K. 2020. On the Fringe: Sheepdogs and Their Status Within Bronze Age Ontologies in Scandinavia. Current Swedish Archaeology. Vol. 28 pp. 99-I20.

Åsberg, C. \& Braidotti, R. 20I8. Feminist Posthumanities: An Introduction. In: Åsberg, C. \& Braidotti, R. (eds), A Feminist Companion to the Posthumanities, pp. I-22. Cham: Springer.

Åsberg, C., Koobak, R. \& Johnson, E. 20I I. Beyond the Humanist Imagination. Nordic Journal of Feminist and Gender Research. Vol. I9(4) pp. 218-230.

Back Danielsson, I.-M. 20I4. Handlingar på gränsen: En hypotes kring hetero- och homoerotiska uttryck på heliga Helgö och närliggande Hundhamra under yngre järnålder. In: Alexandersson, H., Andreeff, A. \& Bünz, A. (eds), Med hjärta och hjärna: En vänbok till professor Elisabeth Arwill-Nordbladh, pp. 259-275. Göteborg: Göteborgs universitet.

Bar-Yosef Mayer, D., Bonsall, C. \& Choyke, A.M. (eds). 2017. Not Just for Show: The Archaeology of Beads, Beadwork, and Personal Ornaments. Oxford: Oxbow Books.

Bartosiewicz, L. I999. Animal Bones from the Cochabamba Valley, Bolivia. In: Gyarmati, J. \& Varga, A. (eds), The Chacaras of War: An Inka Site Estate in the Cochabamba Valley, Bolivia, pp. I7I-I9I. Budapest: Museum of Ethnography.

Bartosiewicz, L. 200I. A Leopard (Panthera pardus L. 1758) Find from the Late Middle Ages in Hungary. In: Buitenhuis, H. \& Prummel, W. (eds), Animals and Man in the Past, pp. I5I-I60. Groningen: ARC-Publicatie 4I.

Bartosiewicz, L. 2006. Mettre le chariot devant le boeuf: Anomalies ostéologiques liées à l'utilisation des boeuf pour la traction. In: Pétrequin, P., Arbogast R.-M., Péterquin A.-M., Van Willigen, S. \& Bailly, M. (eds), Premiers chariots, premiers araires: La diffusion de la traction animale en Europe pendant les IVe et IIIe millénaires avant notre ère, pp. 259-267. Paris: CNRS Editions.

Bartosiewicz, L. 20I2. Show me your Hawk, I'll Tell you who you are. In: Raemaekers, D.C.M., Esser, E., Lauwerier, R.C.G.M. \& Zeiler, J.T. (eds), A Bouquet of Archaeozoological Studies: Essays in honour of Wietske Prummel, pp. I8I-I90. Groningen: Bakhuis \& University of Groningen Library.

Bartosiewicz, L. 2013. Shuffling Nags, Lame Ducks: The Archaeology of Animal Disease. Oxford: Oxbow Books.

Bartosiewicz, L. 2015. Animal Remains from the Langobard Cemetery of Ménföcsanak (NW Hungary). Antaeus. Vol. 33 pp. 249-264.

Bartosiewicz, L. 20I9a. Animal Palaeopathology: Between Archaeology and Veterinary Science. In: Peters, J. (ed.), Animals: Cultural Identifiers in Ancient Societies?, pp. 2736. Rahden/Westf: Verlag M. Leidorf.

Bartosiewicz, L. 20I9b. Late Chalcolithic Animal Exploitation at Arslantepe. In: Balossi Restelli, F. (ed.), Arslantepe Period VII: The Development of a Ceremonial/political 
Centre in the First Half of the Fourth Millennium BCE (Late Chalcolithic 3-4), pp. 263-306. Roma: Sapienza Università di Roma, Dipartimento di Scienze dell'Antichità.

Bartosiewicz, L. 2020. Paleopatología: Una perspectiva posthumanista. Paper delivered at Anthropos 2020, Convención International de Antropología. La Habana, Cuba, 9 al I 2 marzo 2020.

Bartosiewicz, L. 202I. What is a Rare Disease in Animal Palaeopathology? International Journal of Paleopathology. Vol. 33 pp. I3-24.

Bartosiewicz, L. \& Bartosiewicz, G. 2002. 'Bamboo spine' in a Migration Period Horse from Hungary. Journal of Archaeological Science. Vol. 29(8) pp. 8I9-830.

Bartosiewicz, L. \& Choyke, A.M. 1994. Taxonomie und Typologie der Knochenartefakte von St. Blaise. In: Kokabi, M. \& Wahl, J. (eds), Beiträge zur Archäozoologie und Prähistorischen Anthropologie, pp. 263-268. Stuttgart: Konrad Theiss Verlag.

Bartosiewicz, L. \& Choyke, A.M. 2020. Animals Stepping off the Page. In: Bartosiewicz, L. \& Choyke, A.M. (eds), Medieval Animals on the Move: Between Body and Mind, pp. I-I2. Cham: Palgrave.

Bartosiewicz, L., Choyke, A.M. \& Reynolds, F. 2017. Stag do: Ritual Implications of Antler use in Prehistory. In: Bickle, P., Cummings, V., Hofmann, D. \& Pollard, J. (eds), The Neolithic of Europe: Papers in Honour of Alasdair Whittle, pp. I07-I19. Oxford: Oxbow Books.

Bartosiewicz, L., Csiky, G. \& Gyarmati, J. 2008. Emberiességi szempontok és a hagyományos állatvágás két példája (Humane considerations and two examples of traditional slaughter). Animal Welfare, etológia és tartástechnológia. Vol. 4(3) pp. I30-I 49.

Bartosiewicz, L. \& Gál, E. 2008. Symptoms of Aggression on Animal Bones from Archaeological sites. Animal welfare, etológia és tartástechnológia. Vol. 4(I) pp. 3-25.

Bartosiewicz, L. \& Gál, E. 20I8. Ottoman Turkish Influences on Animal Exploitation in I6th-I7th century Hungary. In: Çakırlar, C., Chahoud, J., Berthon, R. \& Pilaar Birch, S. (eds), Archaeozoology of the Near East XII, pp. I9I-206. Groningen: Barkhuis Publishing.

Bartosiewicz, L. \& Gál, E. 202I. The Archbishop's Dinner? Late Medieval Fish from Esztergom-Várhegy-Kőbánya, Hungary. Archaeological and Anthropological Sciences. Vol. I3(I32) pp. I-I4.

Bartosiewicz, L., Kovács, Zs.E., \& Farkas, B. 2013. Pass the Skeleton Key ... Animals in an Early Copper Age Inhumation Burial from Pusztataskony-Ledence I, Hungary. In: Starnini, E. (ed.), Unconformist Archaeology: Papers in Honour of Paolo Biagi, pp. 77-88. British Archaeological Reports IS 2528, Oxford: Tempus Reparatum.

Bendrey, R., Cassidy, J.P., Fournié, G., Merrett, D.C., Oakes, R.H.A. \& Taylor, G.M. 20I9. Approaching Ancient Disease from a One Health Perspective: Interdisciplinary Review for the Investigation of Zoonotic Brucellosis. International Journal of Osteoarchaeology. Vol. 30 pp. 99-108.

Bobrowsky, P.T. I982. Olsen and Olsen's Identity Crisis in Faunal Studies. American Antiquity. Vol. 47(I) pp. I8I-I83.

Boessneck, J. 1990. 25 Jahre, Institut für Palaeoanatomie, Domestikationsforschung und Geschichte der Tiermedizin der Ludwig-Maximilians-Universität, München 1965I990. München: Ludwig-Maximilians-Universität.

Bökönyi, S. I992. The Possibilities of a Cooperation between aAchaeology and Zoology. Bulletino di Paletnologia Italiana. Vol. 83 pp. 39I-40I.

Burkert, W. 1972. Homo Necans: Interpretationen altgriechischer Opferriten und Mythen. Berlin/New York: Walter de Gruyter. 
Choyke, A.M. 1997. The Bone Tool Manufacturing Continuum. Anthropozoologica. Vol. $25-26$ pp. $65-72$.

Choyke, A.M. 200r. Late Neolithic Red Deer Canine Beads and Their Imitations. In: Choyke, A.M. \& Bartosiewicz, L. (eds), Crafting Bone: Skeletal Technologies through Time and Space, pp. 25 I-266. British Archaeological Reports IS 937. Oxford: Tempus Reparatum.

Choyke A.M. 20Iо. The Bone is the Beast: Animal Amulets and Ornaments in Power and Magic. In: Campana, D., Crabtree, P., DeFrance, S.D., Lev-Tov, J. \& Choyke, A.M. (eds), Anthropological Approaches to Zooarchaeology: Colonialism, Complexity, and Animal Transformations, pp. 197-209. Oxford: Oxbow.

Choyke, A.M. 20I2. Hunting the Bezoar Goat: Sympathetic Magic in Early Bronze Age Arslantepe. In: Raemaekers, D.C.M., Esser, E., Lauwerier, R.C.G.M. \& Zeiler, J.T. (eds), A Bouquet of Archaeozoological Studies: Essays in honour of Wietske Prummel, pp. 83-91. Groningen: Bakhuis.

Choyke, A.M. \& Bartosiewicz, L. I994. Angling with Bone. In: Van Neer, W. (ed.), Fish Exploitation in the Past, pp. I77-182. Tervuren: Koninklijk Museum voor Midden Afrika.

Cockram, S. 20I8. Sleeve Cat and Lap Dog: Affection, Aesthetics and Proximity to Companion Animals in Renaissance Mantua. In: Cockram, S. \& Wells, A. (eds), Interspecies Interactions: Animals and Humans between the Middle Ages and Modernity, pp. 34-63. London: Routledge.

Daróczi-Szabó, M., Kovács, Zs.E., Raczky, P. \& Bartosiewicz, L. 2020. Pending Danger: Recent Copper Age Lion (Panthera leo L., I758) Finds from Hungary. International Journal of Osteoarchaeology. Vol. 30(4) pp. 469-48I.

Derrida, J. 2006. A poil devant un chat. In: Derrida, J. \& Mallet, M.-L. (eds), L'animal que donc je suis, pp. I8-28. Paris: Galilée.

Despret, V. 20I3. From Secret Agents to Interagency. History and Theory. Vol. 52 pp. 29-44.

Dobres, M.-A. 2000. Technology and Social Agency: Outlining a Practice Framework for Archaeology. Oxford: Blackwell.

Dobres, M.-A. \& Robb, J.E. 2000. Agency in Archaeology: Paradigm or Platitude. In: Dobres, M.-A. \& Robb, J.E. (eds), Agency in Archaeology, pp. 3-I7. London: Routledge.

Faraone, C. \& Naiden, F.S. (eds). 20I 2. Greek and Roman Animal Sacrifice: Ancient Victims, Modern Observers. Cambridge: Cambridge University Press.

Forchhammer, G., Steenstrup, J.C.H.R. \& Worsaae, J. 1856. Undersøgelser i geologiskantiqvarisk retning part I [Studies in geological-antiquarian direction]. Copenhagen: Kongliga Hofbogtrykker Bianco Luno.

Fredengren, C. 20I3. Posthumanism, the Transcorporeal and Biomolecular Archaeology. Current Swedish Archaeology. Vol. 2I pp. 53-7I.

Fredengren, C. 202I. Beyond Entanglement. Current Swedish Archaeology. Vol. 28 pp. II -33 .

Gentry, A., Clutton-Brock, J. \& Groves, C.P. 2004. The Naming of Wild Animal Species and their Domestic Derivatives. Journal of Archaeological Science. Vol. 3 I pp. 645-65I.

Geppert, P. 1990. Hundeschlachtungen in Deutschland im 19. und 20. Jahrhundert unter besonderer Berücksichtigung der Verhältnisse in München. Dissertation. München, Institut für Paläoanatomie, Domestikationsforschung und Geschichte der Tiermedizin der Universität München.

Grosman, L., Munro, N.D. \& Belfer-Cohen, A. 2008. A I2,000-year-old Shaman Burial from the Southern Levant (Israel). PNAS. Vol. I05 pp. I7665-I7669. 
Guaman Poma de Ayala, F. I6I5[1990]. El primer nueva crónica y buen gobierno. Budapest: Gondolat.

Hazzah, L., Borgerhoof Mulder, M. \& Frank, L. 2009. Lions and Warriors: Social Factors Underlying Declining African Lion Populations and the Effect of Incentive-based Management in Kenya. Biological Conservation. Vol. I42 pp. 2428-2437.

Király, Á. 20I5. Other/World: Mysteries of Bronze Age Life in Northeastern Hungary. Hungarian Archaeology e-journal. 20I5(autumn) pp. I-5. eng_Kiraly_I5O.pdf (archaeolingua.hu),

Kristiansen, K. 20I4. Towards A New Paradigm? The Third Science Revolution and its Possible Consequences in Archaeology. Current Swedish Archaeology. Vol. 22 pp. I I-34.

Lidén, K. \& Eriksson, G. 20I3. Archaeology vs. Archaeological Science: Do we have a case? Current Swedish Archaeology. Vol. 2I pp. I I-20.

Magnell, O., 20II. Sacred Cows or Old Beasts? A Taphonomic Approach to Studying Ritual Killing with an Example from Iron Age Uppåkra, Sweden. In: Pluskowski, A. (ed.), The Ritual Killing and Burial of Animals: European Perspectives, pp. 192-204. Oxford: Oxbow Books.

Masson, M., Molnár, E., [...] Bull, I.D. \& Pálfi, G. 20I3. Osteological and Biomolecular Evidence of a 7000-year-old Case of Hypertrophic Pulmonary Osteopathy Secondary to Tuberculosis from Neolithic Hungary. PLoS One. Vol. 8(เо) e78252.

Milosavljević, M. 202I. Always Angular and Never Straight: Medieval Snakes in Human Graves? In: Bartosiewicz, L. \& Choyke, A.M. (eds), Medieval Animals on the Move: Between Body and Mind, pp. 95-I 19. Cham: Palgrave.

Noe-Nygaard, N. 1987. Taphonomy in Archaeology, with Special Emphasis on Man as a biasing Factor. Journal of Danish Archaeology. Vol. 6 pp. 7-52.

Pelegrin, J. Karlin, C. \& Bodu, P. I988. 'Chaînes opératoires' un outil pour le préhistorien. In: Tixier, J. (ed.), Technologie préhistorique, pp. 55-62. Paris: Editions du CNRS.

Pluskowski, A. 2004. Narwhals or Unicorns? Exotic Animals as Material Culture in Medieval Europe. European Journal of Archaeology. Vol. 7(3) pp. 29I-3I3.

Price, N. 20Io. Passing into Poetry: Viking-Age Mortuary Drama and the Origins of Norse Mythology. Medieval Archaeology. Vol. 54(I) pp. I23-I56.

Raber, K. 20I8. Animals at the Table: Performing Meat in Early Modern England and Europe. In: Cockram, S. \& Wells, A. (eds), Interspecies Interactions: Animals and Humans between the Middle Ages and Modernity, pp. I07-I22. London: Routledge.

Raczky, P. \& Anders, A. 2008. Activity Loci and Data for Spatial Division at a Late Neolithic Site-complex (Polgár-Csőszhalom: A Case Study). In: Bailey, D.W., Whittle, A. \& Hofmann, D. (eds), Living Well Together? Settlement and Materiality in the Neolithic of South-East and Central Europe, pp. 35-53. Oxford: Oxbow.

Ritvo, H. 2007. On the Animal Turn. Daedalus. Vol. I36(4) pp. II8-I22.

Ritvo, H. 2018. Afterword. In: Cockram, S. \& Wells, A. (eds), Interspecies Interactions: Animals and Humans between the Middle Ages and Modernity, pp. 23 I-232. London and New York: Routledge.

Russell, N. 20I2. Social Zooarchaeology: Humans and Animals in Prehistory. Cambridge: Cambridge University Press.

Schibler, J. I98I. Typologische Untersuchungen der cortaillodzeitlichen Knochenartefakte. Die neolithischen Ufersiedlungen von Twann. Band I7. Bern: Archäologischen Dienst des Kantons Bern, Staatlicher Lehrmittelverlag. 
Schrödinger, E. 1935. Die gegenwärtige Situation in der Quantenmechanik. Naturwissenschaften. Vol. 23(48) pp. 807-8I 2.

Sokal, R.R. 1974. Classification: Purposes, Principles, Progress, Prospects. Science. Vol. I 85 pp. III5-II 23.

Stolle, B. 2020. Ritual Slaughter through the Eyes of the Butcher: Perspectives on a Complex Practice. Current Swedish Archaeology. Vol. 28 pp. I8I-200.

Storå, J., Ullén, I. \& Drenzel, L. 2020. Splitting Bodies: A Close-up Study of a South Swedish Bog Deposition from the Pre-Roman Iron Age. Journal of Archaeological Science: Reports. Vol. 34 e. I0262I.

Susat, J., Lubke, H., [...]Nebel, A., \& Krause-Kyora, B. 202I. A 5,000-year-old HunterGatherer already Plagued by Yersinia Pestis. Cell Reports. Vol. 35(13) 109278.

Vanhaeren, M. \& D'Errico, F. 2000. Grave Goods from the Saint-Germain-la Riviere Burial: Evidence for Social Inequality in the Upper Palaeolithic. Journal of Anthropological archaeology. Vol. 24 pp. II7-I34.

Varro, M.T. I97I. Rerum Rusticarum: De Agri Cultura. Budapest: Akadémiai Kiadó.

Vörös, I. 199I. Kutyaáldozatok és kutyatemetkezések a középkori Magyarországon II. [Dog Sacrifices and Burials in Medieval Hungary]. Folia Archaeologica. Vol. 42 pp. I79-I96.

Wells, A. 2018. Blurred Lines: Bestiality and the Human Ape in Enlightenment Scotland. In: Cockram, S. \& Wells, A. (eds), Interspecies Interactions: Animals and Humans between the Middle Ages and Modernity, pp. I23-148. London and New York: Routledge.

Wolfe, C. 2009. Human, All Too Human: 'Animal Studies' and the Humanities. Publications of the Modern Language Association. Vol. I24(2) pp. 564-575. 